\title{
A RESEARCH Vision FOR MUSEums
}

\author{
ADDRESS TO CARE, AAM '09 ON MAY 2, 2009
}

By John W. Jacobsen

CEO \& Co-PI, The White Oak Institute

I love museums, and I love the museum family and these yearly family gatherings. I am particularly honored to be invited to address the CARE community gathered here today because I think you are critical to the salvation of our family.

Our museum family is in danger. Outside economic forces find us vulnerable because of internal divisions and because we don't have our act together. So, I am here on a mission to save museums and to engage your considerable skills in a family intervention, for we have lost our way. Management has failed our mission by focusing on outputs like attendance numbers, and audience researchers have failed management by not shedding light on the connections between the pleasure of learning and attendance or, if you will, between individual gains and a museum's public value. This research vision for museums looks at how you can make that connection and save museums in their hour of need.

We are all museum professionals. We are part of that larger field, with this AAM Big Tent conference hosting our largest family gathering. After the "museum boom" of the Giddy Nineties, there are now more museums than Starbucks (Katz, 2008) - yet many of them are struggling in today's economy and wired lifestyle.

I mentioned that I am particularly fond of these annual family gatherings, where I run into friends and colleagues near the registration desks and in the aisles of AAM's Expo Center. This annual conference has always reminded me of a Lewis Thomas quote from his Lives of a Cell, that Jeanie and I used as one of our marriage readings, over 25 years ago. As you listen to Thomas's description, think of our professional family and of this conference:

"Viewed from a suitable height, the aggregating clusters of medical scientists in the bright sunlight of the boardwalk at Atlantic City, swarmed there from everywhere for the annual meetings, have the look of assemblages of social insects. There is the same vibrating, ionic movement, interrupted by the darting back and forth of jerky individuals to touch antennae and exchange small bits of information...." 
"...Although we are by all odds the most social of all social animals, we do not often feel our conjoined intelligence. Perhaps, however, we are linked in circuits for the storage, processing, and retrieval of information, since this appears to be the most basic and universal of all human enterprises... The circuitry seems to be there, even if the current is not always on." (Thomas, 1974)

I have always thought that Thomas' vision of "conjoined intelligences" is a powerful way of building intelligence and wisdom through collaboration. This was after all, a marriage reading, when joining two intelligences was about removing all impediments to the marriage of true minds. At some level, marriage is about deconstructing silos and building partnerships.

Conjoined intelligence is scalable from two minds in synch, to a family, to a community, to a professional field, to a nation and out to the global electronic village. And so that is why Thomas' quote is heartwarming to me. In research jargon, if I can link behaviors to outcomes, and if I can observe those behaviors, then the outcomes should be happening.

And, anyone who has observed behaviors in AAM's expo hall will recognize Thomas's description of "the darting back and forth of jerky individuals to touch antennae and exchange small bits of information." So, conjoined intelligence must be happening? Right? Yes, ... but in truth, not so much.

The issue with the warm and fuzzies of the quote --that is, if you can get beyond being compared to an insect -- is that the museum family is not operating as a conjoined intelligence because we are dysfunctional in several ways. Think of the advances made in the last twenty years in other fields, such as science and technology, or in the ways history and literature are studied, or in how libraries and public television are evolving their services in the Internet age.

It is hard to say that advances in the museum field have kept pace. Are our museums more effective contributors to our communities now than we were a decade ago? Can we even say that our exhibits are better, even though we now have another decade of accumulated evaluation and research documentation? As Kathy McLane asks, "Are we there yet?"

When the Exploratorium, with help from the National Science Foundation, discovers that clustering topic-related exhibits is an effective strategy to increase dwell time and retention, why don't lots of museums adopt this strategy? Switch over to the museum management side of the aisle, where research is getting even less traction. What is the right size for a given museum in a given market? What share of the community should 
they be engaging? What is the ideal employee to visitor ratio? Although we can throw around some numbers, in most cases, we have neither the data nor the formulas to depend on.

Of course, we have made progress, but it is relatively modest compared to other fields. Minda Borun and the PISEC initiative - the seven factors for family learning - is one example of a researched advance that has been adopted, and we can find institutions that used to be geared to individual children but that are now oriented to the whole family. Security, appearance, and universal design are also advances, but maybe they were just outside societal evolutions that we had to flow with, as we are now with greening museums.

\section{THE NEED FOR EVIDENCE OF PUBLIC VALUE}

But, we can't say that museums have become better in their community impact largely because we have no measure. We may have thirty years or more of visitor studies, but they don't yet connect to this über-question now critical to the field's survival: What impacts are museums as institutions having in their communities? What is the relative worth of a particular museum (not just an exhibit, or film, or school program) as a community asset? We have uplifting stories, but no measurements. Libraries have answers to such questions, with verifiable and consistent numbers, plus the uplifting stories. So do PBS affiliates. Schools are measured, and, regardless of what one thinks of No Child Left Behind, the scoring is working to move schools through innovations in some dimensions.

Our worth is not clear. Note the company that U.S. Sen Tom Coburn (R-OK) and Rep. David Obey (R-WI) assumed for museums when they introduced an amendment to the economic stimulus legislation to prohibit any funds in the bill from going to our family. One version of the amendment included:

\section{"None of the amounts appropriated or otherwise made available by this Act may be used for any casino or other gambling establishment, aquarium, zoo, golf course, swimming pool, stadium, community park, museum, theater, arts center, or highway beautification project, including renovation, remodeling, construction, salaries, furniture, zero-gravity chairs, big screen televisions, beautification, rotating pastel lights, and dry heat saunas." (Coburn, 2009)}

While AAM and others managed to re-instate museums, our aquarium and zoo cousins were not so lucky. However, we don't hear Sen. Coburn cutting off funds for libraries, schools, national parks and universities -- -- they are essential. Museums, on the other hand, he lumped in with "rotating pastel lights and dry heat saunas."

Jim Collins, the business guru and author of "Good To Great," when he addressed the Association of Children's Museums Conference in 2008, observed that like great 
corporations, great museums will be the ones that set goals and measure results, achieving sustainability and growth by managing key performance indicators.

From a management viewpoint, this approach makes a great deal a sense. Operating data provides real information, and so changes in operating data evidence direct impact on management's objectives.

So what are the museum family's key performance indicators? The truth of the matter is, we have no research-quality metrics on museum key performance indicators much less on community impact at an institutional level. I'm not even sure that as a field we could define what those are; much less understand their quantities. Annual attendance has been the most carefully watched metric, yet museums are pursuing far broader community service objectives than simply moving visitors through the turnstile.

Attendance is a dangerously shallow metric measuring only volume, not impact. A museum might increase attendance by screening Batman: A Dark Knight, but what effect does that have on its community impact? Again, because we don't know, and because we have no better metric, management goes for Batman because their board and community judges management's performance primarily on the shallow metric of annual attendance, and the extra revenue can support mission work.

Recently, the grant-seeking museums in Pennsylvania, California and Maryland, and soon in another four states, have been filing their operating data in a standardized, online reporting system called the Cultural Data Project, developed by a consortium of Pennsylvania funding agencies, led by the Pew Charitable Trusts. In about two years, when the recently signed up states are online, an estimated $34 \%$ (Katz, 2009) of grantseeking museums will be reporting their annual operating data through the Cultural Data Project.

There is an initiative we are involved in to standardize museum-operating data nationally - the other $66 \%$ - through the Cultural Data Project reporting system and its wonderful help and telephone-support lines. This may set the stage for national databases of key performance indicators. In addition to informing management directly, this database will provide researchers with an entirely different research tool. But that is a few years away, and the museum field has troubles now. We also have work to do to get ready for this new data.

\section{CuRrent Research SiLOS}

Perhaps you are saying, what does this have to do with me? I am an audience researcher, not an accountant. I'm into learning research, not operating data, or, I'm into learning outcomes, not marketing outputs. Well, that is the crux of the problem and why I am here today. I will make a distinction between your relatively pure and ordered house of audience research, and the chaotic, and money-tainted house of museum research. 
One of the big issues that I see, is that aside from Alan Friedman and a few others, museum directors are not listening to audience research and evaluation findings from federal grant-funded projects, but they are listening to local market research firms, their own operating data, product development focus groups, quantitative interest and satisfaction surveys, and the findings from their most influential focus group, the board of directors.

You, the Committee for Audience Research and Evaluation, in these times of significant change, have the opportunity to harness your findings and skills to inform the urgent evolution of museums into a more sustainable future. We need to integrate audience research with museum research, and we need to do it conceptually, personally and sustainably.

If you follow though on this direction - and you are the only ones who can lead this, the museum field will eventually have: a) a shared research framework and museum models that link individual learning outcomes with a museum's community impacts; b) a merged family of museum and audience research professionals who know each other and communicate regularly, and c) significantly expanded business opportunities for you as researchers once museum managers start to understand the value of integrated audience and museum research and your expert interpretations.

Another way of thinking about the shift I am proposing is that CARE will become CAMRE - the Committee for Audience and Museum Research and Evaluation.

The museum field has not moved forward on consistent research framework for a number of reasons, including its inherent sibling squabbling and identity huffs. There are external reasons - such as differing governance policies and community expectations, there are shifting grounds - new types of museums and museum impacts, and there are reasons internal to our family. Because we can do something about these, the internal issues are what I want to address today.

Why are we a dysfunctional family? Within the umbrella term of "museum and audience research," there are discipline silos with competing values, methodologies and objectives, as well as separate professional communities, departments within a museum, and funding objectives.

Marketing and development departments do some institutional research, but education and exhibit departments are often suspect of their methodologies and results; besides, no department has the time to study other department's reports.

We also feel overworked and underpaid; in the bottom of our hearts we all know we should spend more time with each other's research and with exploring its implications with colleagues, but our lists are long and the family must be fed. 
But the most significant issue is structural. Most evaluation and research work going on in the CARE and VSA communities is assessing visitor outcomes (learning) and not community outputs and public value. Museum managers on the other hand are making decisions based on anticipated operating outputs and less on audience learning outcomes.

We are not the Andrews family sisters, or the Everly Brothers or the Jonas Brothers, because we are not on the same page and singing in harmony. We are not even the Trump family, vying for a daddy's attention. We do have godfathers, however, in the NSF, NEA, NEH and IMLS, and they have been the most successful at getting us to shape up as a field. We are an idiosyncratic lot; each institution and service provider is proud of its uniqueness and romantically inspired to chart its own identity. Yet that pride is standing in the way of advancing and perhaps saving our field.

We have to connect the dots between what visitors get out of their individual learning experiences and what their community gets out of the museum. I am happy to see a number of sessions at the upcoming VSA conference that bridge to institutional research, so there are pathways being made between the houses already.

We need to get rid of the prejudice that marketing and money are somehow separate from learning and mission. In a free-choice field such as museums, learning is what we are selling, and gate attendance is evidence of how many people are choosing learning. We need to accept shared frameworks for research. We need to share data definitions and ways of reporting and accessing them. Then we might be able to conjoin our intelligences and advance our museum family's community worth. So how do we do all that?

\section{Museums' NeEd To Establish OUR WORTH}

The late Stephen Weil, in his wonderful essay "Making Museums Matter," talks about a museum's worth to its community. He recognizes that some institutions can be more worthy than others, based on what they are capable of accomplishing. However -- -and he wrote this nine years ago, he is aware of our family's unease with being held accountable:

"... the awkward fact still remains that, for a variety of reasons, the museum field

has never really agreed -- or, at least until recently, has scarcely even sought to agree -- on some standard by which the relative worthiness or merit or excellence of its constituent member institutions might be measured."(Weil, 2002).

The intellectual challenge is to shift the evaluation of the impact of specific programs on target audiences to the impact of the whole collection of programs on the whole community, and to connect that impact to a sustainable business model. Al DeSena at the NSF observes: 
"Many have a difficult time making a strong case for how their proposed projects will be sustained after grant funding, let alone whether the work will contribute to the sustainability of the organizations. It's in everyone's interests to have a way of

connecting the dots of the 'system' between project viability, organizational vitality, and field-wide advancement."(DeSena, 2006)

President Obama reminds us that a time of crisis can also be one of great opportunity. Now is the time museum managers need to help to make better decisions.

There is a silver lining to these economic storm clouds. Attendance and membership renewals are generally holding if not up, reflecting the value museum experiences offer compared to pricier alternatives.

John and Anita Durel suggest that "more than ever, people are valuing meaningful experiences... with the trend away from a focus on material possessions toward a desire to do something meaningful for oneself and for others."(Durel, 2009)

We evaluate individual exhibits and programs on whether they achieve their objectives, which often involve communication of what Beverly Serrell calls the "big idea." Museums, however, may be playing a different game, one more focused on process than content. To the Durel's, a museum's crucial and essential (their terms) role in the community may be as a facilitator for you to do something meaningful for yourself and others -- the content of what you do is less important here than the kind of process you engage with through the museum.

From the museum's perspective, and their interest in the overall community impact, what is important is that learning is going on, civic connections are being made, identities are being shaped, ideas are being inspired and role models explored.

\section{THE ROLE FOR LOGIC MODELS}

Some are using logic models as a way of connecting needs to resource investments, to activities, to outputs, then to outcomes, and finally to impacts and social values, and there are also network and other models that can help plan and then evaluate projects and systems.

There is a very useful logic model in Gary Silverstein's section in the NSF's Framework for Evaluating ISE Projects (NSF, 2008) that shows the logic sequence for the Informal Science Education division. It makes clear how ISE's worth can be evaluated on whether they are "advancing the informal education field." This illustrates how investments connect to outcomes in measurable ways; it also controls how they want to be evaluated. They've made up the rules of the game they are playing, and are now keeping score. 
But let's consider zooming upward a bit, to think about the logic model for a whole museum, or even for the museum field as a whole. What needs are museums responding to? What resources do we bring? What are the activities, outputs and outcomes we expect? What are the broader impacts of museums in America? If we had such a logic diagram for a single museum, or for a category of museums or even for the whole field, we would have the tools to evaluate our worthiness.

This seems like a good idea, so why can't we have logic models for museums? It's not my job to conjure these, but it could be yours. Perhaps we need to start with individual museums or one sector of the museum field, and then see if aspects of the model can be generalized. I did go far enough to see that it could be done, and that the bricks were there to build the model. Filling in the boxes in each of the columns won't be as much of a problem as finding out how to connect them horizontally and numerically so that we can measure the logic model's efficiency of transforming inputs into community outputs and public value.

To adopt a shared logic model, we need to start the process with the humility to say "Yes. That other person's idea is good, and let's build on it." Or the even greater humility to say "before we try to invent something ourselves, let's see if there are best practices and standardized frameworks that we can adopt."

There should be debate about whether one unifying museum model is possible or even desirable. If schools and libraries are sheep, museums are cats - fiercely independent, so the perception goes.

Of course each museum will have a distinct logic model, and for many, this is the right place to start: develop logic models for those specific museums that seek an institutional evaluation framework to monitor yearly efficiency and impact.

Imagine a collation of several hundred of those museum-specific logic models - all the needs together, all the resources, all the activities, all the outputs, all the outcomes, all the impacts in long lists. Would we see patterns and groupings? Would we be able to roll-up the detail into useful categories?

I am an optimist and an everything-is-connected type of guy, so I believe we would see patterns, and that a unified, field-wide logic model is possible in some form, though I can see why some will believe otherwise.

The debate, however, is beside the point. Outside pressures like federal and other large funding agencies are forcing shared evaluation metrics, imposing a field-wide logic model on us by default.

The museum field's logic model, or research framework, if you articulate it first, is likely to feel like it has been here all along. It will not fit all museums, and it is likely to 
be somewhat vague - dare I say generic? - but it may fit those museums who choose to live by AAM accreditation standards.

\section{Changing THE ReSEARCh Questions}

The central question of most audience studies to date has been "did program $X$ help audience $Y$ get outcome $\mathrm{Z}$ ?" To save museums, the central question must become "how can museum $X$ better serve its community and increase its public value?"

In his introduction to the recent John Cotton Dana reprint, Stephen Weil says:

"[Dana] emphasized - long before marketing concepts had become current - the importance of connecting program decisions to the needs and interests of the

museum's community. "Learn what aid the community needs," he said, and "fit the museum to those needs." He speculated on the extent to which a museum might be an enterprise that could be better managed as a business."(Weil, 1999)

So, the challenge is to find the best fit between a museum's learning services and its community's learning needs. Research and evaluation can be the tools for finding the right fit.

\section{THe Museum Logic Model}

An outcome-based logic model for a museum can be the basis for its evaluation, for trying out theories, for monitoring trends and for focusing research. Using logic models for museums will be a big step forward in organizing ourselves as a field and will provide us with Jim Collins' key performance indicators. The challenge is not creating the logic model; many of you could draft one tonight. The real challenge is to get all of you to adopt one set of shared standards. Then you can expand the circle to include the funding agencies (NSF and IMLS in particular) and the key museum associations. After that, the rest of the museum field. But the child must be conceived and raised in this house, before its coming of age presentation to our funding godfathers.

And the only way that all of you will embrace their shared standards is if all of you are involved in their creation and development. Fortunately now, a community of practice such as yourselves can work on this together through social web media - the CARE and VSA communities can crowdsource data standards and the museum logic model.

Let me describe where I think we are at the moment, and you will recognize in the synthesis the great work of other museum researchers and learning theorists. I am under no illusion that we are a unified field and that a logic model must fit all museums. Rather I am focused on museums with community service missions. That is the sector where I believe the potential for proving our public value is greatest.

The most recent paradigm for museums, which have a long history of other paradigms, was established by the American Association Museums' Excellence and Equity in the 
late ' 80 's and early ' 90 's. It recognized a shift that had been happening for decades by affirming the museum's prime purpose was educational, with collections serving that goal. In the 1992 report issued by the AAM Task Force on Museum Education, chaired by Bonnie Pitman, the first of its ten principles provide the foundation for the museum field:

"Assert that museums place education -- in the broadest sense of the word -- at the center of their public service role. Assure that the commitment to serve the public is clearly stated in every museum's mission and is central to every museum's activities." (American Association of Museums, 1992)

Another layer of community was added on top of education, with AAM's later America's Museums: Building Community initiative which said:

"The American Association of Museums urges all museums to embrace their responsibility to be active and collaborative civic institutions and to respond to the aspirations and needs of citizens in their communities."

(American Association of Museums, 2006)

Today education and community-building are widely accepted as museum purposes within our family, although there are plenty of museums, formed in previous paradigms, that continue with other purposes. Additionally, new purposes, such as workforce development, civic identity and increasing tourism are emerging.

However, in our current paradigm, "museums place education at the center." This core purpose provides our common answer to Stephen Weil's challenge: Education is the common purpose of all museums.

George Hein has pushed this purpose further with the question of "why educate?" His answer is to "build a better and more democratic society" (Hein, 2006), which adds to John Cotton Dana's "build a better and more civil society"(Dana, 1999). George provides us with a direction for the purpose, a goal to strive for. This desire to improve society is inherently progressive, with the implication that the educational purpose of the museum is ultimately progressive education.

Museums are about positive change. We look out to what our community needs, and we use our resources to make positive changes and so earn public value by addressing some of our community's needs.

Our logic model must build on our strengths in the resources column of the logic model. These strengths are more than just our collections, buildings and staff. Museums are unique among other free choice learning organizations, like public television and libraries, in that our learning services are based on physical experiential learning, or what John Dewey called learning from experience. Experiential learning happens in real 
time, and in a physical context, not on a video screen or written page. Learners put their hands on a Van de Graff generator and their hair stands on end, they stand in the Holocaust boxcar and feel a chill, they enroll in a teen intern program and advance their job skills, and they soar over $\mathrm{K} 2$ on their way to Everest in the IMAX® theater.

Two models of the museum experience provide a field-wide foundation for the activities column in the logic model, one based on learning and the other based on visitor satisfaction.

John Falk and Lynn Dierking's research on the museum experience established three contexts necessary for museum learning: the personal, sociocultural and physical contexts (Falk and Dierking, 2000). Marilyn Hood established categories of benefits that the visitor gets out of museum experiences, including "spending quality time with friends and family" and "experiencing something new," and in third place, "learning something new"(Hood, 1983).

The outputs column has all the operating data museums collect, but that quickly vanishes into the mists of memory. The outcomes column has all the data you've collected that should bring back evidence of positive individual outcomes. Collectively, these should show greater impacts on education, community-building and quality of life for our intended audiences. Perhaps we have come to a point where we can meet Stephen Weil's challenge to agree on measurements.

\section{PrIOR WORK}

This plea for the visitor studies community to help save museums is a seconding, supporting motion to Alan Friedman's excellent 2007 article "The Great Sustainability Challenge: How Visitor Studies Can Save Cultural Institutions in the 21st Century" (Friedman, 2007). He observes that three interacting dimensions are critical to museum sustainability: financial, intellectual and social, and he urges the visitor study community to undertake evaluations in all three domains as a way to save museums.

An attempt to standardize evaluation was made in 1997 by the Museum Learning Collaborative, with their article in the Journal of Museum Education (Schauble et. al, 1997). This system had a great deal of thought and experience, again reflecting the same desire to integrate and standardize our evaluations. The Institute for Learning Innovation's In Principle, In Practice (Falk et al., 2007) also articulated a new direction for research practice and informal learning.

John Falk and Beverly Sheppard have a similar thought that establishing evaluation criteria is critical to museum sustainability, and they list four evaluation categories: Public Value, Internal Value, External Value and Resources and Finance (Falk and Sheppard, 2006). There is also the triple-net evaluation system, not to mention formalized systems by the IRS and the Cultural Data Project. 
Recently, Mary Ellen Munley's team was able to demonstrate individual outcomes and link them to greater social impacts, by using new methodologies to trace individual outcomes, in this case urban teens who had participated in a US Holocaust Museum program, to a wider community impact through the individuals' networks.

All these systems by your field's great minds should be studied and synthesized, as a way of informing the development of agreed-upon ways of quantifying public value.

Frankly, I don't care what is decided upon as long as some standards are set, however generic they need to be. What I am proposing today is a process for this community to develop standards for evaluating museums. As a Standing Professional Committee of the AAM, you are the professionals in the best position to do this.

The ticking clocks, adding urgency, include the AAM accreditation processes that are undergoing significant revision. Now is the time to work with the commissioners to shape those field-wide standards, which they want the practioners to establish. The Cultural Data Project is a force for common reporting and a new, consistent and important source of evidence. Another deadline looms in the prospect of federal formula grants, which will demand evaluation metrics; unless we provide them with thoughtful standards first, they will be of someone else's invention. Maybe they'll evaluate us by how many rotating pastel lights we have or dry heat saunas.

Recently, when I was complaining about the disconnect between management's focus on outputs and evaluators' focus on outcomes, Barbara Flagg had the kindness and brilliance to connect the two mathematically, in what I'll call Flagg's Equation: $\mathrm{I}=\mathrm{O}^{2}$, or, Impact equals Outputs times Outcomes. The principle is simple: if your research sample is truly representative of the whole (a big "if"), and if your evaluation shows that, say, $65 \%$ of the sample has retained the program's key nugget of information, then the attendance to that program can be multiplied by $65 \%$, to quantify its community impact. If the attendance output is one million visitors, then you could say that 650,000 people got the message, and in so doing, measure the worthiness of what you are evaluating.

The Flagg equation hypothesizes that scaling up our findings on individuals might be a way to calculate a museum's impact on its community, and I would love someone here to test this hypothesis with some research. Martin Storksdeick points out that the real challenge is getting a sample that is truly representative of the whole million visitors, and the Heisenberg Uncertainty Principle applies as visitors talking to researchers suddenly seem to have better memories and higher opinions than the average bear.

But the CARE community cannot do this on your own. You have to collaborate with management. They use different research tools because they have different needs, and those needs will continue. A research framework for museums also needs participation and buy-in by museum management and finance. 


\section{MUSEUM RESEARCH}

Museum management, particularly at larger museums, already uses research to inform decisions. For instance, traveling exhibitions are judged on operating data from previous sites, as well as specific market research related to marketing and positioning. However, there is no community of practice for museum research yet. Each new museum director has new thoughts, and board members offer pro-bono research. There are promising pockets of standardization on the operating data side, but few shared frameworks and many short memories.

\section{AudienCE RESEARCH}

However, this side of the museum family, the audience research side, is operating with much more conjoined intelligence than museum research. You do have your professional act together (compared to other sectors). Thirty years after Chan Screven, Marilyn Hood, Stephen Bitgood, George Hein and others started studying visitors scientifically, you have matured, and are ready now to take on larger challenges.

You have built a strong framework for learning research. You know if learning is happening and if the intended learning outcomes are met. For over thirty years, this community of practice has been coalescing into a professional field. You share a secret language, like double-blind, front-end SurveyMonkeys. And you have built on each other's findings through conferences and peer-reviewed journals -- acting, in this sector of the museum family, very much like Lewis Thomas' scientists in Atlantic City.

\section{The MARriage of Museum Research AND Audience Research}

Museum research is an interesting mate for you to consider, if it can be shaped up a bit and made more presentable. Museum research doesn't even own a proper logic model, much less a nice formal paradigm for those special Getty events. Museum research is all over the map, swinging from economic impact to Meyers Briggs to mall intercepts to phone forums at a board member's wink. And what gossip! It's a revolving door of research vendors over there, seldom the same ones twice. Also, between you and me, most of those museum management vendors are from across the tracks. Ad agency firms, making a bundle, but also corporate types, like Bain \& McKinsey, doing it for free!

Among this mess of commissioned studies, however, museum research includes a significantly different methodology, which adheres to accounting and financial recordkeeping standards. Through operating data, we can look at an existing institution with $x$-ray vision, measuring its temperature if you will, in such areas as number and length of museum learning engagements in a year, ratios of staff and volunteers, facility size, sources of revenue, both earned and support, and such institutional character indexes like staff turnover rates, and the number of community partnerships. But this vast supply of revealing data typically has its brief moment in the sun, perhaps for a board 
retreat, and then vanishes. Operating data is the value that management research brings to the marriage. And you can do the studies instead of those ad agency and McKinsey types.

\section{A Museum Research Vision}

My research vision for museums is that we work together as a family to save museums in this caustic economy. To achieve this vision, we will need to:

- Dismantle the silos separating categories of research and work together with respect

- Marry audience and museum research to advance learning and institutional impact

- Recognize and build upon the prior work of our peers by building museum evaluation models to frame and connect our research

- Standardize research definitions to compare and publish meta-data

- Expand professional and organizational skills to embrace both audience and museum research

Some of the outcomes from the successful marriage of museum and audience research and their conjoined intelligences include:

- Healthier museums

- A broader, more exciting, more essential, more influential and better paid professional life for you as CARE expands to CAMRE

- Substantial advances for the museum family as a whole, similar to those enjoyed by libraries in the past two decades that will build the real and perceived value of museums in America until they seen as truly indispensable and essential to America's health and prosperity.

- And to bring back George Hein for the impact finale: That better museums build a better and more democratic society.

Today, I have made a case for expanding your research to include museum research working with management using operating data as another interdisciplinary source of evidence to improve our understanding of how free choice learning works in the marketplace and how we can make it work better.

This is how this room full of great minds can save our field. Think of yourselves as the agents of change in the museum field by establishing and then measuring how museums will be evaluated. My colleague Mary Ann Munley neatly articulated the paradigm change as "a shift from the focus on individual change to a focus on social change while connecting the dots between the two" (Munley, 2009). Saving museums is not a trivial task, but if we can conjoin our intelligences in a marriage of aligned minds, it will be an exciting family adventure.

Thank you. 


\section{REFERENCES}

American Association of Museums. (1992). Excellence and Equity: Education and the Public Dimension of Museums. Baltimore, MD: Collins Lithographing, Inc.

American Association of Museums (2006). From AAM Board resolution (passed on Aug. 7, 2006). America's Museums: Building Community. Washington, D.C.

Coburn, Sen. Tom (R-OK) (2009). Amendment 309. Retrieved May 2, 2009 from http://coburn.senate.gov/public/index.cfm?FuseAction=Files.View\&FileStore_id=f 52e138c-d7d2-496d-be5c-a5e3ca74ab42

Dana, John Cotton. (1999). The New Museum: Selected Writings by John Cotton Dana . Newark, NJ: The Newark Museum Association and the American Association of Museums.

DeSena, Alphonse PhD. (2006) Program Director, Informal Science Education Program, National Science Foundation, as quoted in White Oak Associates' Forum '06.

Durel, John and Anita. (2009). 2009 Will Be a Pivotal Year for Museums and Nonprofits. AASLH Dispatch, February.

Falk, John H and Beverly Sheppard. (2006). Thriving in the Knowledge Age. Lanham, MD: AltaMira Press

Falk, John H., Lynn Dierking and Susan Foutz. (2007). In Principle, In Practice: Museums as Learning Institutions. Lanham, MD: AltaMira Press.

Falk, John H. and Lynn Dierking. (2000). Learning from Museums: Visitor Experiences and the Making of Meaning. Walnut Creek, CA: AltaMira Press

Friedman, Alan J. (2007). The Great Sustainability Challenge: How Visitor Studies Can Save Cultural Institutions in the $21^{\text {st }}$ Century. Visitor Studies Association, May 27.

Hein, G.E. (2006). "Museum Education," in S. MacDonald, editor, A Companion to Museum Studies, Oxford: Blackwell Publishing, Chapter 20.

Hood, Marilyn G. (1983). Staying Away: Why People Choose Not to Visit Museums. Museum News 61, no. 4

Katz, Phil. (2008). Phil Katz, Assistant Director for Research, American Association of Museums). E-mail correspondence to John Jacobsen.

Katz, Dr. Phil. (2009). Phil Katz calculations based on an IMLS survey

Munley, Mary Ellen. (2009). Mary Ellen Munley, Principal of MEM \& Associates. E-mail correspondence to John Jacobsen, April 21. 
National Science Foundation. (2008). Using Logic Models to Identify Desired Impacts and Audience Objectives by Gary Silverstein. Framework for Evaluating Impacts of Informal Science Education Projects - Report from a National Science Foundation Workshop, 35-40

Schauble, L., Leinhardt, G., \& Martin, L. (1997). A Framework for Organizing a Cumulative Research Agenda in Informal Learning Contexts. Journal of Museum Education, 22, (2\&3), 3-8.

Thomas, Lewis (1974). The Lives of a Cell. New York, NY: Bantam Books

Weil, Stephen (1999). The New Museum: Selected Writings by John Cotton Dana Introduction by Stephen E. Weil. Newark, NJ: The Newark Museum Association and the American Association of Museums.

Weil, Stephen. (2002). Making Museums Matter. Washington, D.C.: The Smithsonian Institution 